\title{
PERBEDAAN JARAK TANAM DENGAN METODE LONGLINE BERBINGKAI TERHADAP PERTUMBUHAN RUMPUT LAUT Eucheuma spinosum
}

\section{Differences of planting distance using the longline framed method on the growth of seaweed Eucheuma spinosum}

\author{
Fadhillah Sudrian Barnus ${ }^{1}$, Indah Anggraini Yusanti ${ }^{1 *}$, Sofian ${ }^{1}$ \\ ${ }^{1}$ Program Studi Ilmu Perikanan Fakultas Perikanan dan Kelautan UPGRI Palembang \\ *Corresponding author: indahayusanti@gmail.com
}

\begin{abstract}
ABSTRAK
Rumput Laut Eucheuma spinosum merupakan alga golongan coklat yang memiliki nilai ekonomis dan banyak dibudidayakan oleh masyarakat pesisir di Indonesia. Jenis ini banyak dibudidayakan karena mudah dan murah serta prospek pasar yang cukup baik. Penelitian ini bertujuan untuk mengetahui pertumbuhan harian dan pertumbuhan mutlak rumput laut dengan jarak tanam berbeda menggunakan metode long line berbingkai. Penelitian dilakukan selama 50 hari, menggunakan 3 perlakuan yaitu jarak tanam $20 \mathrm{~cm}, 40 \mathrm{~cm}$ dan 60 $\mathrm{cm}$ serta pengulangan sebanyak 3 kali, dengan berat awal rumput laut berkisar 50 gr. Data yang dikumpulkan pada penelitian ini yaitu pertumbuhan harian (DGR), pertumbuhan mutlak (AGR) dan parameter kualitas air. Hasil yang diperoleh untuk pertumbuhan harian dan pertumbuhan mutlak rumput laut tertinggi adalah perlakuan P3 dengan jarak tanam $60 \mathrm{~cm}$ sebesar 6.36\%/hari dan seberat 1053.9 gr, dan kualitas air pada lokasi penelitian masih terbilang baik untuk pertumbuhan rumput laut (Eucheuma spinosum).
\end{abstract}

Kata kunci: Jarak Tanam, Metode Longline, Rumput Laut Eucheuma spinosum, Pertumbuhan

\section{ABSTRACT}

Eucheuma spinosum seaweed is a brown algae that has economic value and is widely cultivated by coastal communities in Indonesia. This type is widely cultivated because it is easy and cheap as well as a fairly good market prospect. This study aims to find out the daily growth and absolute growth of seaweed with different planting distances using the framed long line method. The research was conducted for 50 days, using 3 treatments, namely planting distance $20 \mathrm{~cm}, 40 \mathrm{~cm}$ and $60 \mathrm{~cm}$ and repetition as much as 3 times, with the initial weight of seaweed ranging from $50 \mathrm{gr}$. The data collected in this study are daily growth (DGR), absolute growth $(A G R)$ and water quality parameters. The result obtained for daily growth and absolute growth of seaweed is the highest $P 3$ treatment with a planting distance of $60 \mathrm{~cm}$ by $6.36 \% /$ day and weighing $1053.9 \mathrm{gr}$, and the water quality at the research site is still fairly good for seaweed growth (Eucheuma spinosum).

Keywords: Planting Distance, Longline Method, Seaweed (Eucheuma spinosum), Growth

\section{PENDAHULUAN}

Rumput laut merupakan salah satu tumbuhan tingkat rendah yang perawakannya (habitusnya) relatif sulit dibedakan antara akar, batang dan daunnya, karena hampir sebagian tubuhnya disebut dengan talus. Rumput laut terdiri dari 3 (tiga) divisi utama berdasarkan kandungan pigmen yang cenderung dominan yaitu 
Rhodophyta (alga merah), Phaeophyta (alga coklat), dan Chlorophyta (alga hijau) (Indrawati et al., 2007 dalam Ferawati, et al., 2016).

Jenis rumput laut yang umum dibudidayakan oleh masyarakat salah satunya adalah rumput laut Eucheuma spinosum. Menurut Farnani, et al., (2011), Eucheuma spinosum merupakan algae makro bentik yang dimanfaatkan sebagai bahan baku dalam pembuatan tepung agaragar, keraginan dan alginate. Bahan baku tersebut dimanfaatkan dalam berbagi industry, seperti industri tekstil, kosmetik, dan makanan. Disamping itu dengan meningkatnya minat terhadap rumput laut yang dijadikan bahan baku maka semakin meningkat pula kebutuhan akan rumput laut dan mendorong untuk dilakukannya kegiatan budidaya rumput laut secara intensif untuk meningkatkan produksi rumput laut tersebut. Salah satu metode dalam budidaya rumput laut adalah metode long line berbingkai. Kelebihan metode ini menurut Soegiarto (2005) dalam Farnani, et al., (2011) yaitu pertumbuhan Eucheuma spinosum lebih cepat dan lebih menghemat material. Selain itu budidaya Eucheuma spinosum dengan metode ini tidak tergantung pada substrat dasar perairan sehingga dimungkinkan Eucheuma spinosum ini terbebas dari hama yang hidup pada dasar perairan yang berlumpur dan berkarang.

Penelitian ini bertujuan untuk mengetahui pertumbuhan harian, pertumbuhan mutlak rumput laut dan kualitas air selama penelitian rumput laut Eucheuma spinosum. Penelitian ini diharapkan dapat menjadi sumber informasi tambahan mengenai pengaruh jarak tanam rumput laut dalam upaya peningkatan produksi dan budidaya rumput laut bagi masyarakat pesisir pantai.

\section{METODE PENELITIAN}

Penelitian dilaksanakan selama 2 bulan yaitu pada bulan Oktober sampai dengan bulan Desember 2018 di Balai Besar Perikanan Budidaya Laut Lampung (BPBBL). Alat yang digunakan pada penelitian ini meliputi timbangan digital, konstruksi berbingkai, pelampung, alat tulis, tali, stereofoam, jangkar, botol plastic, karter, $\mathrm{pH}$ meter, refraktometer, sechidisk, sedangkan bahan yang digunakan adalah rumput laut Eucheuma spinosum.

Penelitian ini menggunakan

Rancangan Acak Lengkap dengan 3 perlakuan yaitu jarak tanam rumput laut Eucheuma spinosum $20 \mathrm{~cm}$ sebagai perlakuan $1(\mathrm{P} 1), 40 \mathrm{~cm}(\mathrm{P} 2)$ dan $60 \mathrm{~cm}$ (P3) dengan ulangan sebanyak 3 kali setiap masing-masing perlakuan dalam penelitian. Berat awal rumput laut yang ditebar adalah seberat 50 gr. Peliharaan dilakukan selama 50 hari dan setiap 10 hari dilakukan kegiatan sampling. Sampling rumput laut dilakukan dengan cara diambil sebanyak $30 \%$ jumlah rumput laut dari setiap perlakuan.

Umur bibit rumput laut yang digunakan berkisar antara 25 - 30 hari, dengan kriteria memiliki cabang yang banyak, tidak terdapat bercak, tidak terdapat tumbuhan penempel dan bebas dari penyakit. Selanjutnya proses penanaman bibit tersebut dilakukan dengan mengikat bibit rumput laut pada tali jalur dengan jarak tanam sebesar $20 \mathrm{~cm}(\mathrm{P} 1), 40$ $\mathrm{cm}$ (P1), $60 \mathrm{~cm}$ (P3) seseuai perlakuan masing-masing. Bibit diikat pada tali ris berukuran $1 \mathrm{~mm}$ dengan simpul hidup. Selanjutnya tali jalur diikatkan pada kontruksi dengan jarak $1 \mathrm{~m}$ pada setiap jalur. Bibit rumput laut ditanam secara serentak atau bersamaan dan merata untuk mengurangi stress pada rumput laut. Kemudian diberikan pelampung berupa botol air mineral kosong pada setiap jalur untuk mempertahankan kedalaman tetap pada ketinggian yang diinginkan. Gambar perlakuan dalam penelitian selengkapnya disajikan pada Gambar 1. 


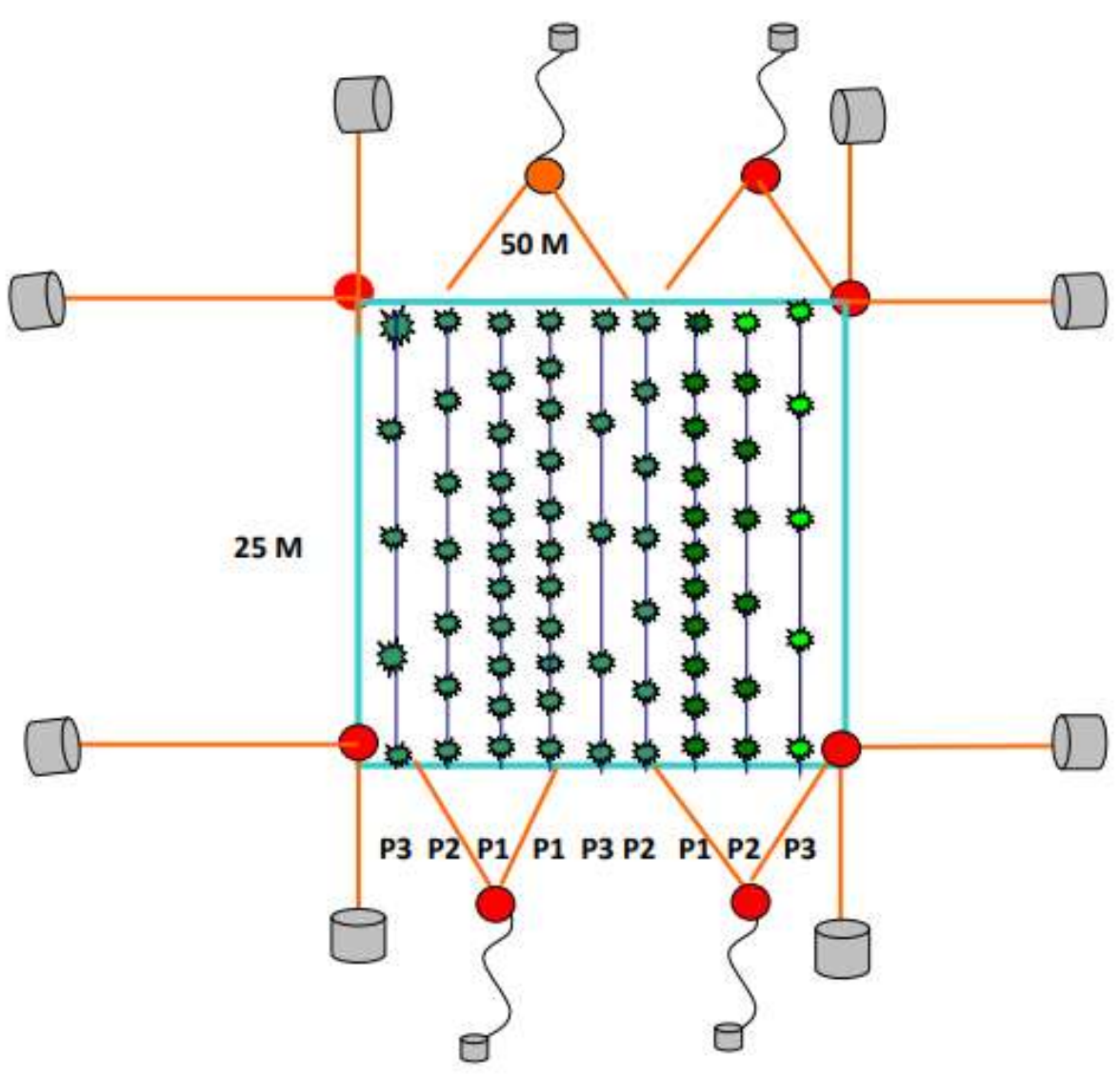

Gambar 1. Denah Jarak Tanam Rumput Laut Dengan Metode Longline Berbingkai.

\section{Parameter yang diamati}

Pertumbuhan harian rumput laut dihitung dengan mengacu pada rumus yang digunakan oleh Hendri, et al., (2018).

$$
\operatorname{DGR}=\left\{\left[\frac{W \mathrm{t}}{W_{0}}\right] 1 / T-1\right\} X 100 \%
$$

Keterangan :

DGR $=$ pertumbuhan $(\% /$ hari $)$

$\mathrm{Wt}=$ berat rumput laut pada akhir penelitian $(\mathrm{g})$

W0 =berat rumput laut pada awal penelitian $(\mathrm{g})$

$\mathrm{T} \quad=$ waktu pengamatan (hari)

Sedangkan pertumbuhan mutlak rumput laut dalam penelitian ini dihitung dengan mengacu pada penelitian Hendri, et al., (2018) sebagai berikut.

$$
A G R=W t-W 0
$$

Keterangan :

AGR = Pertumbuhan mutlak rumput laut (g)

$\mathrm{Wt}=$ berat akhir bibit rumput laut $(\mathrm{g})$

Wo = berat awal rumput laut $(\mathrm{g})$

Sedangkan, pengamatan kualitas air yang diamati dalam penelitian ini meliputi arus, suhu, kedalaman, kecerahan, salinitas, dan $\mathrm{pH}$.

\section{HASIL DAN PEMBAHASAN}

Pertumbuhan harian dan mutlak rumput laut pada masing- masing perlakuan dalam penelitian ini disajikan pada Gambar 2 dan Gambar 3 sebagai berikut. 


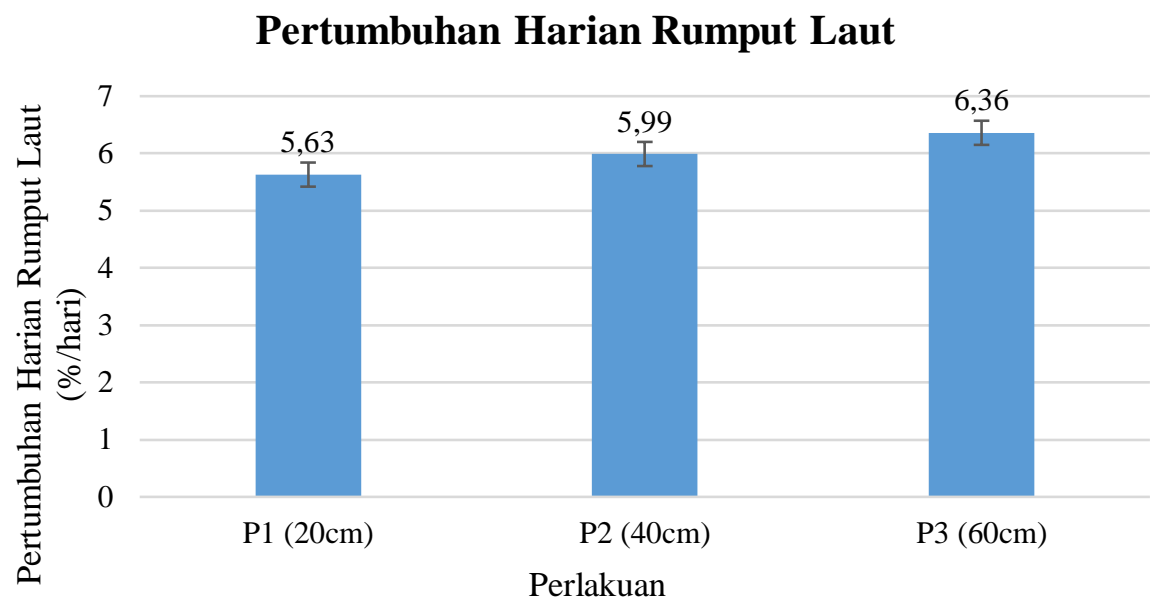

Gambar 2. Pertumbuhan Harian Rumput Laut

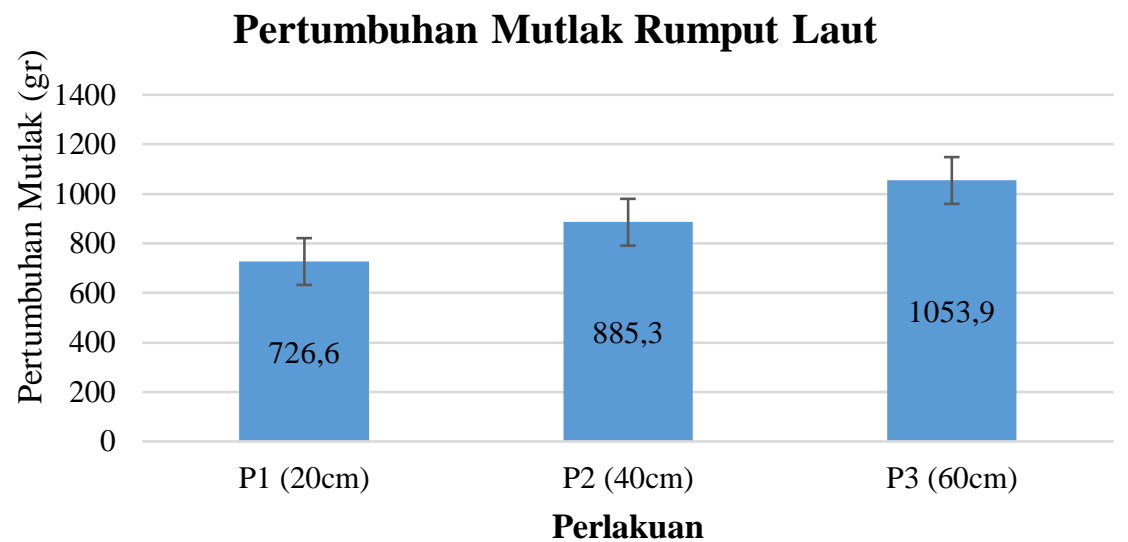

Gambar 3. Pertumbuhan Mutlak Rumput Laut

Dari Gambar 2 dan Gambar 3 terlihat bahwa terjadi peningkatan pertumbuhan pada rumput laut selama penelitian berlangsung. Pertumbuhan harian rumput laut tertinggi diperoleh pada perlakuan P3 sebesar $6.36 \%$ /hari dan yang terendah pada perlakuan P1 sebesar $5.63 \%$ /hari, sedangkan pertumbuhan mutlak rumput laut tertinggi didapatkan pada perlakuan P3 sebesar 1053.9 gr dan terendah pada perlakuan P1 sebesar 726.6 gr. Berdasarkan hasil Ansira diketahui bahwa jarak tanam rumput laut berpengaruh sangat nyata terhadap pertumbuhan harian dan pertumbuhan mutlak rumput laut. Hal ini diduga karena adanya jarak tanam rumput laut yang menyebabkan thalus pada rumput laut mampu menyerap unsur hara lebih baik.
Dugaan tersebut diperkuat oleh pendapat Supit (1989) dalam Suswantoro (2016) yang menyatakan bahwa persaingan antara thalus dalam hal kebutuhan matahari, zat hara dan ruang gerak sangat mempengaruhi pertumbuhan rumput laut. Lebih lanjut Ruswahyuni et al., (1998) dalam Suswantoro (2016); Farnani, et al., (2011) menambahkan bahwa proses pertumbuhan rumput laut sangat tergantung pada salinitas, gelombang laut, kedalaman, kecepatan arus, intensitas sinar matahari untuk melakukan proses fotosintesis, dimana melalui proses tersebut sel-sel rumput laut dapat menyerap unsur hara yang dapat memacu pertumbuhan harian rumput laut melalui aktifitas pembelahan sel. 
Parameter kualitas perairan yang diukur pada penelitian ini meliputi arus, suhu, kedalaman, kecerahan, salinitas dan pH disajikan pada Tabel 1 berikut.

Tabel 1. Data Kualitas Air Selama Penelitian

\begin{tabular}{ccccccc}
\hline $\begin{array}{c}\text { Minggu } \\
\text { ke- }\end{array}$ & $\begin{array}{c}\text { Arus } \\
(\mathbf{c m} / \mathbf{s})\end{array}$ & $\begin{array}{c}\text { Suhu } \\
\left({ }^{\mathbf{0}} \mathbf{C}\right)\end{array}$ & $\begin{array}{c}\text { Kedalaman } \\
(\mathbf{m})\end{array}$ & $\begin{array}{c}\text { Kecerahan } \\
(\mathbf{m})\end{array}$ & Salinitas & pH \\
& 25 & 29 & 19,1 & 8 & 32 & 8,24 \\
1 & 30 & 29 & 18 & 9 & 28 & 8,64 \\
3 & 27 & 29 & 19 & 8 & 30 & 8,33 \\
5 & & & & & & \\
\hline
\end{tabular}

Hasil pengukuran kecepatan arus pada lokasi penelitian berkisar antara $25-$ $30 \mathrm{~cm} / \mathrm{s}$. Diduga nilai kecepatan arus tersebut termasuk dalam nilai optimum untuk budidaya rumput laut. Hal ini sejalan dengan pendapat Arisandi dan Farid (2014) yang menyatakan bahwa arus yang baik untuk pertumbuhan rumput laut berkisar antara $20-40 \mathrm{~cm} /$ detik. Jika arus terlalu tinggi menyebabkan kerusakan pada rumput laut, sebaliknya jika arus terlalu rendah akan mengakibatkan nutrisi yang ada di perairan kurang baik. Fungsi arus dalam budidaya rumput laut salah satunya untuk mengangkut nutrisi yang diperlukan untuk pertumbuhan rumput laut dan membantu membersihkan kotoran yang menempel pada rumput laut.

Suhu pada lokasi penelitian diperoleh berkisar antara $28{ }^{\circ} \mathrm{C}-29{ }^{\circ} \mathrm{C}$. Hasil pengukuran ini menunjukkan bahwa lokasi sampling sesuai untuk pertumbuhan rumput laut. Hal ini diperkuat oleh pendapat yang dinyatakan oleh Hidayatulbaroroh (2020); Suswantoro (2016) bahwa suhu yang optimum untuk pertumbuhan rumput laut adalah $26-32{ }^{\circ} \mathrm{C}$. Adanya perubahan fluktuasi nilai suhu menurut Kordi (2000) dalam Ramadhan (2020) dipengaruhi oleh parameter lainnya, diantaranya musim, cuaca, waktu pengukuran, kedalaman air serta kecerahan suatu perairan. Lebih lanjut Tomascik et al., (1997) dalam Susilowati et al., (2012) menambahkan bahwa suhu dapat mempengaruhi fotosintesa di laut baik secara langsung maupun tidak langsung. Pengaruh secara langsung yaitu suhu berperan untuk mengontrol reaksi enzimatik dalam proses fotosintesis. Suhu yang tinggi dapat menaikkan laju maksimum fotosintesis, sedangkan pengaruh tidak langsung yaitu dalam merubah struktur hidrologi perairan yang dapat mempengaruhi distribusi fitoplankton.

Pengukuran kedalaman perairan diperoleh nilai berkisar $18 \mathrm{~m}-19,1 \mathrm{~m}$. Nilai ini melebihi nilai optimum untuk budidaya rumput laut. Menurut Farid (2008) dalam Ferawati, et al., (2016), rumput laut di Indonesia akan tumbuh dengan baik pada kedalaman $20-30 \mathrm{~cm}$, karena umumnya penetrasi cahaya matahari dapat mencapai kedalaman tersebut. Perairan yang terlalu dangkal akan menghambat pertumbuhan rumput laut, karena dekat dengan dasar perairan yang jika teraduk dapat menimbulkan kekeruhan sehingga mengganggu proses fotosintesis. Lebih lanjut Haris (2018) menambahkan bahwa perairan dengan kedalaman air yang terlalu dekat dengan dasar sangat rentan terhadap sedimentasi penumpukan kotoran dari sisa pakan dan hasil metabolisme ikan.

Pada pengukuran kecerahan diperoleh nilai berkisar antara $8 \mathrm{~m}-9 \mathrm{~m}$. Nilai kecerahan ini mengindikasikan bahwa lokasi budidaya rumput laut tersebut tergolong baik. Menurut Haris (2019), kecerahan berperan dalam menyediakan sinar matahari yang diperlukan oleh tumbuhan air dan fitoplankton dalam melakukan fotosintesis. Adanya variasi nilai kecerahan pada penelitian ini diduga dipengaruhi oleh kedalaman lokasi dan waktu sampling. Hal ini dikuatkan oleh pendapat Akib et al (2015) yang 
menyatakan bahwa adanya perbedaan kecerahan di setiap lokasi pengambilan sampel berhubungan dengan kedalaman lokasi, substansi sedimen, kecepatan arus dan waktu dilakukannya pengamatan.

Nilai salinitas pada lokasi penelitian berkisar antara $28-32$ ppt. Nilai ini termasuk nilai salinitas yang optimal untuk budidaya atau pertumbuhan rumput laut. Menurut Ditjenkanbud (2005) dalam Susilowati (2012), kisaran salinitas yang baik untuk rumput laut adalah 28 - 35 ppt. Hasil pengukuran $\mathrm{pH}$ perairan pada lokasi penelitian berkisar antara 8,24 hingga 8,64. Nilai tersebut menunjukan bahwa pada lokasi penelitian cocok untuk pertumbuhan rumput laut Eucheuma spinosum.

\section{KESIMPULAN}

Hasil penelitian yang telah
dilakukan
disimpulkan pertumbuhan harian dan mutlak rumput laut (Eucheuma spinosum) tertinggi diperoleh pada perlakuan P3 (jarak tanam $60 \mathrm{~cm}$ ) sebesar $6,36 \% /$ hari dan $1.053,9 \mathrm{gr}$, sedangkan nilai kualitas air yang diperoleh masih mendukung untuk pertumbuhan rumput laut.

\section{DAFTAR PUSTAKA}

Akib, A., Litaay, M., Ambeng., dan Asnady, M. 2015. Kelayakan Kualitas Air Untuk Kawasan Budidaya Eucheuma cottoni Berdasarkan Aspek Fisika, Kimia Dan Biologi Di Kabupaten Kepulauan Selayar. Jurnal Pesisir dan Laut Tropis. Vol.1(1) : 25-36.

Arisandi, A., dan Farid, A. 2014. Dampak Faktor Ekologis terhadap Sebaran Penyakit Ice-ice. Jurnal Kelautan. Vol 7 (1) : 20-25.

Farnani, Y.H., Cokrowati, N., dan Farida, N. 2011. Pengaruh Kedalaman Tanam Terhadap Pertumbuhan Eucheuma spinosum Pada Budidaya dengan Metode Rawai. Jurnal Kelautan. Vol.4(2) : 176186.
Ferawati, E., Widyartini, D. S., dan Insan, I. 2014. Studi Komunitas Rumput Laut Pada Berbagai Substrat Di Perairan Pantai Permisan Kabupaten Cilacap. Jurnal Scripta Biologica. Vol.1(1) : 55-60.

Haris, R.B.K., dan Yusanti, I.A. 2018. Studi Parameter Fisika Kimia Air Untuk Keramba Jaring Apung Di Kecamatan Sirah Pulau Padang Kabupaten Ogan Komering Ilir Provinsi Sumatera Selatan. Jurnal Ilmu-ilmu Perikanan dan Budidaya Perairan. Vol.14(2) : 57-62. DOI: http://dx.doi.org/10.31851/jipbp.v1 3i2.2434.

Haris, R. B. K., dan Yusanti, I. A. 2019. Analisis Kesesuaian Perairan Untuk Keramba Jaring Apung Di Kecamatan Sirah Pulau Padang Kabupaten Ogan Komering Ilir Provinsi Sumatera Selatan. Jurnal Lahan Suboptimal. Vol. 8 (1). Hlm : 20-30.

DOI: https://doi.org/10.33230/JLSO.8. 1.2019.356.

Hendri, M., Rozirwan., dan Handayani, Y. 2018. Untung Berlipat Dari Budidaya Rumput Laut Multi Manfaat. Lily Publisher. Yogyakarta. 180 Hal.

Hidayatulbaroroh, R. 2019. Teknik Dan Finansial Budidaya Rumput Laut (Eucheuma cottonii) Dengan Metode Jalur Di Kelompok Tani Mitra Bahari Desa Tanjung Pademawu Pamekasan Madura. Jurnal Vastuwidya. Vol. 2(2) : 90103.

Parenrengi, Andi, Rahman Syah dan Emma Suryati. 2012. Budi Daya Rumput laut Penghasil karaginan (Karaginofit). Badan Penelitian Pengembangan Kelautan dan Perikanan Kementerian Kelautan 
dan Perikanan Republik Indonesia. Jakarta.

Ramadhan, R., dan Yusanti, I.A. 2020. Studi Parameter Studi Kadar Nitrat Dan Fosfat Perairan Rawa Banjiran Desa Sedang Kecamatan Suak Tapeh Kabupaten Banyuasin. Jurnal Ilmu-ilmu Perikanan dan Budidaya Perairan. Vol 15(1) : 3741. DOI: http://dx.doi.org/10.31851/jipbp.v1 5i1.4407.

Susilowati, T., Rejeki, S., Dewi, E.N., dan Zulfitriani. 2012. Pengaruh
Kedalaman Terhadap Pertumbuhan Rumput Laut (Eucheuma cottonii) Yang Dibudidayakan Dengan Metode Longline Di Pantai Mlonggo, Kabupaten Jepara. Jurnal Saintek Perikanan. Vol. 8(1) : 1-6.

Suswantoro, A. 2016. Pertumbuhan dan Produksi Rumput Laut Eucheuma Spinosum dengan Metode Tali Ganda Di Perairan Laguruda Kabupaten Takalar. Skripsi. Program Studi Budidaya Perairan Fakultas Pertanian Universitas Muhammadiyah Makassar. $62 \mathrm{Hal}$. 
